\title{
Elektrody do zgrzewania oporowego ze spiekanego kompozytu miedzi z tufem wulkanicznym
}

\author{
Resistance welding electrodes \\ made from sintered copper composite \\ with volcanic tuff
}

\section{Streszczenie}

W artykule przedstawiono charakterystykę materiałów stosowanych na elektrody do zgrzewania oporowego oraz opisano procesy zużycia i regeneracji tego typu elektrod. Zaprezentowano nowy materiał mogący znaleźć zastosowanie na elektrody do zgrzewania rezystancyjnego - spiekany kompozyt na osnowie miedzi zawierający cząstki tufu wulkanicznego. Przedstawiono proces wytwarzania takiego kompozytu oraz wybrane właściwości. Opisano wyniki badania mikrostruktury, twardości, temperatury mięknienia oraz przewodności elektrycznej i gęstości. Dodatek tufu wulkanicznego do miedzianej osnowy korzystnie wpływa na właściwości kompozytu zwiększając odporność na wysokie wartości temperatury oraz twardość. Dodatek $5 \%$ obj. powoduje niewielkie zmniejszenie przewodności elektrycznej materiału, której wartość odpowiada wartościom dla typowych materiałów na elektrody.

Słowa kluczowe: elektrody kompozytowe, zgrzewanie rezystancyjne

\begin{abstract}
The article presents the characteristics of the materials used for the resistance welding electrodes and describes the processes of wear and regeneration of this type of electrode. Presents new material that could be used for resistance welding electrodes - sintered copper-based composite containing particles of volcanic tuff. The article shows a process for producing such a composite as well as selected properties. This paper describes the results of the microstructure, hardness, softening temperature, and electric conductivity. Addition tuff to copper matrix makes positive effect on the properties of the composite, increases resistance to high temperature and hardness. The addition of $5 \%$ vol. causes a slight decrease in the electrical conductivity of the material, the value of which corresponds to the values for typical materials for electrodes.
\end{abstract}

Keywords: composite electrodes, resistance welding

\section{Wstęp}

Spajanie materiałów jest dziedziną inżynierii materiałowej $w$ której istotną rolę odgrywają procesy zgrzewania oporowego, wykorzystywane do łączenia elementów m.in. w przemyśle motoryzacyjnym, AGD czy przemyśle lotniczym.

Procesy zgrzewania oporowego polegają na trwałym połączeniu elementów $w$ wyniku nagrzania obszaru styku łączonych przedmiotów przepływającym przez nie prądem elektrycznym i odkształcenia plastycznego tego obszaru siłą docisku $[1,2]$. Do wywarcia docisku i doprowadzenia prądu służą elektrody. Wykonuje się je z materiałów od których wymaga

Dr hab. inż Janusz Mikuła, prof. PK; mgr inż. Michał Łach - Politechnika Krakowska im. Tadeusza Kościuszki. 
się m.in. [3]:

- wysokiej przewodności elektrycznej i cieplnej,

- wysokiej temperatury mięknienia,

- małej skłonności do tworzenia się połączeń dyfuzyjnych lub adhezyjnych ze zgrzewanymi materiatami,

- dużej twardości w temperaturze zgrzewania,

- niskich kosztów wytwarzania.

Wymagania te związane są w znacznym stopniu z trwałością elektrod, określaną powszechnie jako liczba zgrzein wykonanych między kolejnymi ostrzeniami (regeneracją) elektrody.

Chodzi tu głównie o zachowanie stabilnej struktury i wysokiej twardości, gdyż znaczne powiększenie powierzchni roboczej elektrody spowodowane odkształceniem wymaga regeneracji elektrody lub korekty prądu zgrzewania [4]. W produkcji wielkoseryjnej z zastosowaniem mechanizacji i automatyzacji trwałość elektrod ma ogromne znaczenie, gdyż ich zużycie i konieczność wymiany powodują straty związane nie tylko z kosztem materiału lecz także bardzo niekorzystne przestoje na liniach produkcyjnych. Elektrody o wysokiej trwałości są więc bardzo pożądanym produktem mającym olbrzymie zastosowanie w przemyśle. Koncerny samochodowe prowadzą ciągłe badania nad zwiększeniem trwałości elektrod i zagadnienie to jest i będzie ciągle aktualne, a wszelkie osiągnięcia w tym zakresie są niezwykle cenne.

Dostępne na rynku materiały na elektrody są znormalizowane (norma ISO 5182). Są to przeważnie stopy miedzi dwu- lub trzyskładnikowe. Powyższa norma podaje 3 grupy materiałów na elektrody. Grupa A są to stopy miedzi zawierające takie dodatki stopowe jak $\mathrm{Cr}$, Zr, Ag, Co, Be, Ni, Si, grupę B stanowią głównie spieki miedzi z wolframem, natomiast do grupy $\mathrm{C}$ zakwalifikowano stopy miedzi umacniane dyspersyjnie $\mathrm{Al}_{2} \mathrm{O}_{3}$.

Grupa A: Typ 1. Nie ulepszane cieplnie stopy o wysokiej przewodności i średniej twardości, kute formy, które są umacniane w procesie wytwarzania poprzez obróbkę plastyczną na zimno.

Typ 2. Stopy twardsze niż 1 typu, których właściwości mechaniczne zostały uzyskane przez obróbkę cieplną w trakcie wytwarzania lub poprzez połączenie obróbki cieplnej i formowania na zimno.

Typ 3. Stopy poddane obróbce cieplnej posiadające lepsze właściwości mechaniczne niż stopy 2. typu lecz niższe przewodnictwo elektryczne od stopów 1. i 2. typu.

Typ 4. Stopy o pewnych specjalnych właściwościach, które w pewnych przypadkach mogą być otrzymywane poprzez obróbkę plastyczną na zimno lub obróbkę cieplną. Stopy tego typu niekoniecznie są wymienne $z$ innymi.

Grupa B: W grupie tej wyróżnia się sześć rodzajów materiałów w oparciu o zastosowane składniki:

Typ 10 i 11: Spiekane materiały na bazie miedzi i wolframu.

Typ 12: Spiekane materiały na bazie miedzi i węglika wolframu.
Typ 13: Spiekane i przerabiane plastycznie materiały na bazie molibdenu.

Typ 14: Spiekane i przerabiane plastycznie materiały na bazie wolframu.

Typ 15: Spiekane materiały na bazie wolframu i srebra

Grupa C: Grupa ta składa się z dwóch rodzajów materiałów, wytwarzanych przez wewnętrzne utlenianie lub stopowanie mechaniczne.

Największą trwałością z dostępnych na rynku elektrod charakteryzują się elektrody miedziane umacniane dyspersyjnym tlenkiem aluminium $\left(\mathrm{Al}_{2} \mathrm{O}_{3}\right)$, wytwarzane technologią metalurgii proszków.

Dodatek poszczególnych składników do miedzi zwiększa trwałość elektrod, a także wpływa na jakość wykonywanych połączeń zgrzewanych. Stopy zawierające $\mathrm{Al}_{2} \mathrm{O}_{3}$ posiadają wysoką konduktywność i dosyć wysoką twardość. Ich główną zaletą jest jednak znacznie wyższa temperatura mięknienia, która wpływa na zmniejszenie deformacji elektrody i ma decydujący wpływ na długość pracy elektrod.

Elektrody zgrzewalnicze poddawane są cyklicznym naciskom i nagrzewaniu, dlatego wymaga się stosowania na elektrody materiałów nie tylko o wysokiej przewodności elektrycznej i twardości, lecz również zachowujących swoje właściwości w temperaturze procesu zgrzewania. W powszechnie stosowanych materiałach elektrodowych przeznaczonych do zgrzewania stali stosuje się mechanizmy umocnienia roztworowego, wydzieleniowego lub zgniotowego, a przewodność elektryczna wynosi $50-80 \%$ przewodności czystej miedzi, twardość do około $240 \mathrm{HV}$ oraz temperatura mięknięcia do około $500{ }^{\circ} \mathrm{C}$ [4]. Od trwałości elektrod zależą między innymi: przebieg i wydajność operacji zgrzewania, jakość i powtarzalność właściwości złączy oraz jakość wyrobów. Od wysokiej trwałości elektrod zależy możliwość stosowania mechanizacji i automatyzacji procesów zgrzewania seryjnie produkowanych wyrobów [1].

Do najistotniejszych czynników od których zależy trwałość elektrod zaliczyć należy: gatunek stopu miedzi użytego na elektrodę, temperatura pracy, rozwiązanie konstrukcyjne elektrody i stosowany system chłodzenia. Ze względu na wysoką trwałość wskazane są na elektrody wieloskładnikowe stopy miedzi o wysokiej temperaturze rekrystalizacji i zachowujące znaczną twardość w temperaturze podwyższonej [4].

Przeprowadzenie procesu zgrzewania bez ekspulsji, klejenia elektrod do powierzchni zgrzewanych elementów, uzyskanie zgrzein o prawidłowej budowie metalograficznej jest możliwe dzięki dobraniu materiału na elektrody o właściwym składzie chemicznym, adekwatnym do gatunku zgrzewanego materiału. Skład chemiczny elektrod decyduje o sposobie zachowania się materiałów elektrody i elementu zgrzewanego we wzajemnym styku, czyli będzie decydować o tym czy nagrzewanie elementu nastąpi od środka detali lub od zewnątrz (styku z elektrodami) oraz czy elektrody będą się kleić do elementów zgrzewanych.

Materiały na elektrody są charakteryzowane przez: 
- przewodność elektryczną właściwą (\% IACS; MS/m),

- twardość (HV; HB),

- temperaturę mięknięcia $\left({ }^{\circ} \mathrm{C}\right)$.

Ściśle ze składem chemicznym materiału wiąże się jego przewodność elektryczna, lecz zależy ona również od zastosowanej obróbki cieplnej, która nadaje stopom miedzi właściwą twardość i wyznacza im tzw. graniczną temperaturę mięknięcia. Jeżeli elektrody są utwardzane przez zgniot to temperatura mięknięcia odpowiada temperaturze rekrystalizacji [1].

Jednym z głównych czynników, które wpływają na trwałość elektrod jest temperatura do której nagrzewa się część robocza podczas tworzenia zgrzeiny. Zależy ona od parametrów takich jak natężenie prądu zgrzewania i czas jego przepływu. Gdy wspólnie działają nacisk i temperatura (nierzadko przekracza ona temperaturę mięknięcia materiału elektrodowego), podczas pracy elektrody następuje powiększanie się jej średnicy roboczej [5].

Przykłady zużycia elektrod przedstawiono na rysunku 1.
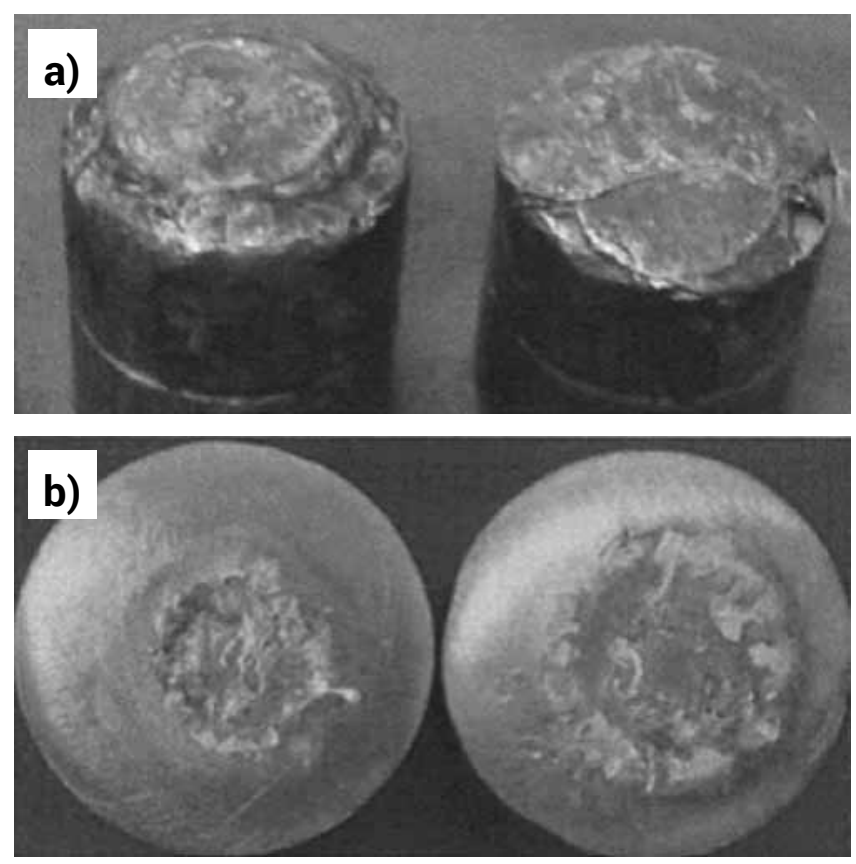

Rys. 1. Przykłady zużycia elektrod: a) przy zgrzewaniu stali, b) przy zgrzewaniu aluminium [6]

Fig. 1. Electrode wear in welding: a) steel, b) aluminum [6]

Skutkuje to zmniejszeniem gęstości prądu i nacisku jednostkowego i prowadzi do zmniejszenia się średnicy jądra zgrzeiny, a tym samym do spadku wytrzymałości połączenia. Gdy zjawisko to występuje po wykonaniu niewielkiej liczby zgrzein, wymagane jest częstsze korygowanie kształtu części roboczej (ostrzenie) elektrod. Polega ono na usunięciu z roboczej części elektrody warstwy zmiękczonej. Liczba regeneracji wpływa na całkowitą liczbę zgrzein uzyskaną przez elektrodę, aż do jej całkowitego zużycia [5].

Ponieważ istnieje wiele czynników decydujących o przydatności danego materiału na elektrody do zgrzewania oraz z częstego braku możliwości ich ilościowego określenia (niektórych z nich), często o przydatności materiału decydują próby zgrzewania. Ich wyniki należy traktować jako porównawcze, gdyż zależą one od rodzaju zgrzewarki, parametrów zgrzewania, siły docisku, rodzaju i wymiarów materiału zgrzewanego oraz stanu jego powierzchni [7].

Wyniki badań potwierdziły, iż istnieje ścisła korelacja twardości części roboczej materiału elektrody od temperatury jej pracy $[1,4]$. Ze względu na wymaganą wysoką trwałość, na elektrody do zgrzewania oporowego wskazane są stopy miedzi o wysokiej temperaturze rekrystalizacji i zachowujące znaczną twardość w podwyższonej temperaturze [4].

Stopy spełniające te wymagania to głównie stopy umacniane dyspersyjnie tlenkami, węglikami, azotkami czy borkami. Podobnie wygląda porównanie zmian wymiarowych w zależności od liczby zgrzein dla miedzi chromowej i miedzi umacnianej dyspersyjnie, co przedstawiono na rysunku 2.

Technologia metalurgii proszków oferuje unikalne rozwiązania przy wytwarzaniu kompozytów umacnianych cząstkami lub dyspersyjnie. Wiele jednostek naukowych prowadzi badania nad wytworzeniem kompozytowych elektrod umacnianych tlenkami, azotkami lub innymi materiałami ceramicznymi. Materiałem, który może posłużyć do umocnienia miedzi jest porowaty tuf wulkaniczny składający się z ceramicznych faz tlenkowych (głównie glinokrzemiany np. sanidyn) [11,12].

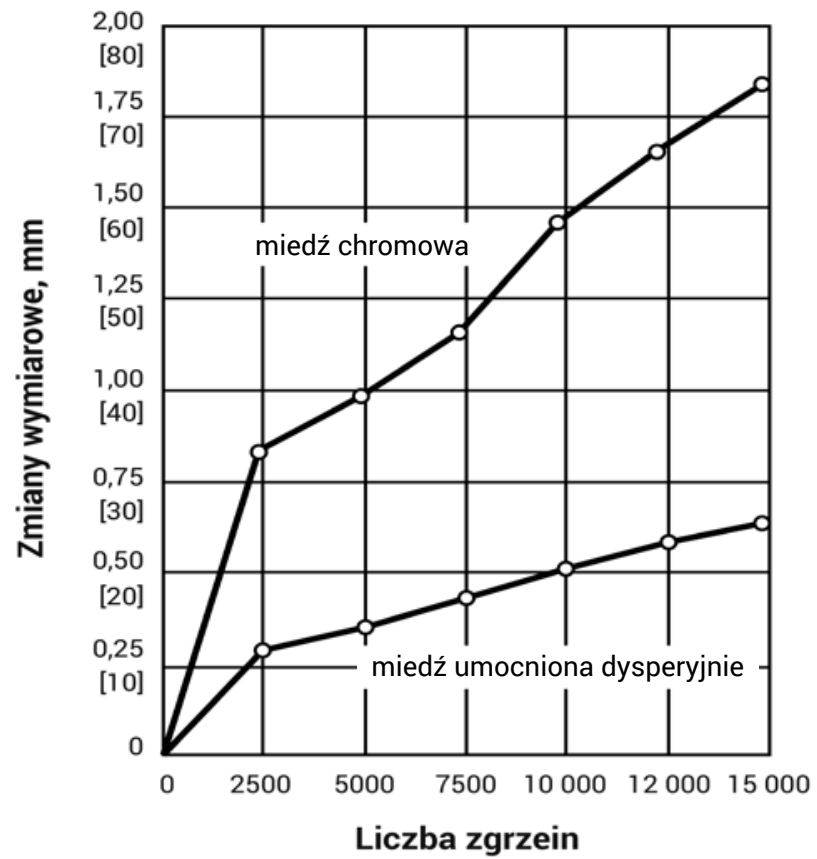

Rys. 2. Zależność zmian wymiarowych średnicy elektrod od liczby wykonanych zgrzein dla miedzi chromowej i miedzi umacnianej dyspersyjnie [8]

Fig. 2. Comparative electrode wear of dispersion-strengthened copper and copper chromium [8]

\section{Cel i zakres pracy}

Celem pracy było zaprezentowanie nowego materiału mogącego posłużyć do wytwarzania elektrod 
zgrzewalniczych, jakim jest kompozyt miedzi z tufem wulkanicznym. W pracy przedstawiono sposób wytwarzania takich kompozytów oraz scharakteryzowano materiał umacniający - tuf filipowicki. Zakres badań obejmował: badania mikrostrukturalne, badania przewodności elektrycznej, badania temperatury mięknienia, badania gęstości oraz wstępne badania trwałości elektrod.

\section{Materiał do badań}

Do badań wykorzystano elektrolityczny proszek miedzi wyprodukowany przez Przedsiębiorstwo Produkcyjno-Handlowe EUROMET z Trzebini.

$\mathrm{Na}$ rysunku 3 przedstawiono morfologię proszku miedzi użytej do badań. Widoczny jest dendrytyczny kształt cząstek proszku, charakterystyczny dla proszków otrzymywanych elektrolitycznie. Skład chemiczny proszku przedstawia tablica 1
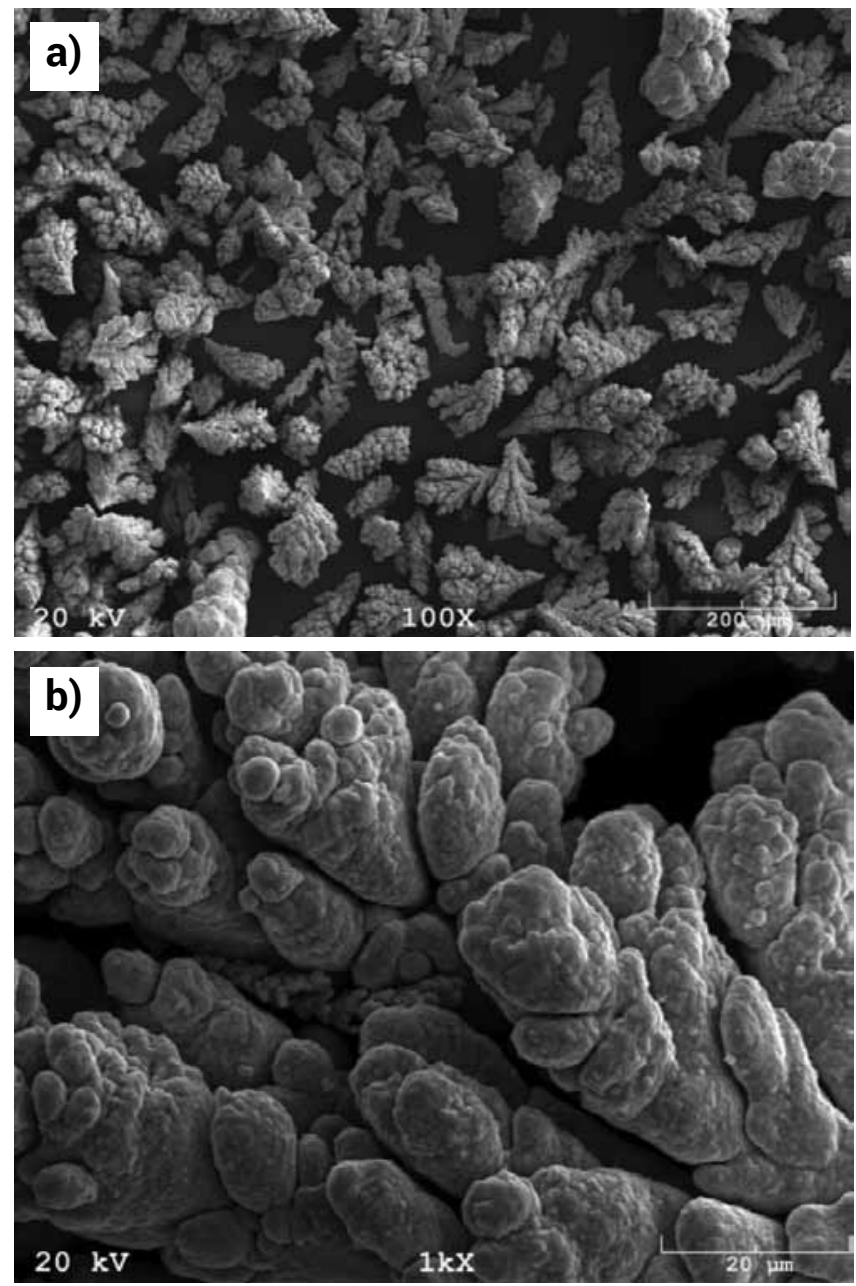

Rys. 3. Morfologia ziaren proszku miedzi użytego do badań

Fig. 3. Morphology of electrolitic copper powder
Jako umacniające cząstki ceramiczne postanowiono wprowadzić do osnowy miedzi rozdrobniony tuf wulkaniczny pochodzący z okolic Krzeszowic, zwany tufem filipowickim. Tufy filipowickie to tufy i tufity porfirowe występujące pomiędzy Karniowcami a Filipowicami oraz w Myślachowicach. Posiadają strukturę porfirową z fenokryształami skalenia. Barwa tufów filipowickich jest czerwono-różowawa, czasem z białymi plamami wtórnego kalcytu lub zielonymi smugami chlorytu. Są tworami czerwonego spągowca (ok. $290 \mathrm{mln}$ lat) [9].

W tufie filipowickim jako główny składnik występuje sanidyn oraz minerały takie jak: kaolinit, biotyt i illit a także kwarc.

Tuf filipowicki zawiera liczne ziarna skaleni potasowych (sanidynu) a także drobne blaszki biotytu. Podrzędnie pojawia się skorodowany kwarc, skaleń może wykazywać objawy kaolinizacji, a biotyt jest częściowo schlorytyzowany [10]. Tuf jest silnie alkaliczny, zawiera około 8,5-12\% $\mathrm{K}_{2} \mathrm{O}$, podczas gdy ilość $\mathrm{Na}_{2} \mathrm{O}$ jest niewielka. Korzystne parametry fizyko-mechaniczne powodowały, że był on chętnie stosowany w budownictwie jako surowiec łatwy w obróbce, o dobrych właściwościach termoizolacyjnych. Dyfraktogram tufu filipowickiego przedstawiono na rysunku 4. Wszystkie zidentyfikowane na dyfraktogramie piki pochodzą of faz $\mathrm{K}\left(\mathrm{AlSi}_{3} \mathrm{O}_{8}\right)$ - sanidyn oraz od $\mathrm{SiO}_{2}$.

Badania porozymetryczne metodą BET wykazały, że wartość powierzchni właściwej dla tufu w postaci naturalnej wynosi około 9,708 $\mathrm{m}^{2} / \mathrm{g}$.

Na rysunku 5 przedstawiono obrazy mikroskopowe SEM tufu wulkanicznego w postaci skały. Widoczne są wyraźnie występujące w tufie kryształy sanidynu. Rysunek 6 przedstawia natomiast tuf rozdrobniony w postaci proszku, który posłużył do wytworzenia kompozytów.

\section{Metodyka badań}

Rozdrobniony i przesiany tuf został poddany prażeniu $\mathrm{w}$ temperaturze $850^{\circ} \mathrm{C}$, aby pozbyć się wody krystalicznej, która mogłaby być uwalniana w trakcie spiekania w temperaturze $900^{\circ} \mathrm{C}$. Dodatkowo prażenie miało na celu pozbycie się substancji organicznych mogących znajdować się w cząstkach tufu. Mieszanie proszków miedzi i tufu przeprowadzono w obrotowym mieszalniku typu Turbula w ciągu 4 godzin. Wytworzono mieszanki o zawartości 5,15 i 30\% obj. tufu. Tuf wprowadzono w postaci proszku o uziarnieniu $<40 \mu \mathrm{m}$ oraz $<5 \mu \mathrm{m}$.

Wszystkie próbki wykonano metodą jednostronnego prasowania na prasie hydraulicznej przy ciśnieniu

Tablica I. Skład chemiczny proszku miedzi

Table I. The chemical composition of copper powder

\begin{tabular}{|c|c|c|c|c|c|c|c|}
\hline Składnik & $\mathrm{Cu}$ & $\mathrm{Pb}$ & $\mathrm{Fe}$ & $\mathrm{SO}_{4}^{-2}$ & $\mathrm{O}_{2}$ & $\mathrm{H}_{2} \mathrm{O}$ & $\mathrm{Cz} . \mathrm{n}$. \\
\hline$\%$ mas. & 99,71 & 0,027 & 0,002 & 0,0029 & 0,16 & 0,026 & 0,019 \\
\hline
\end{tabular}




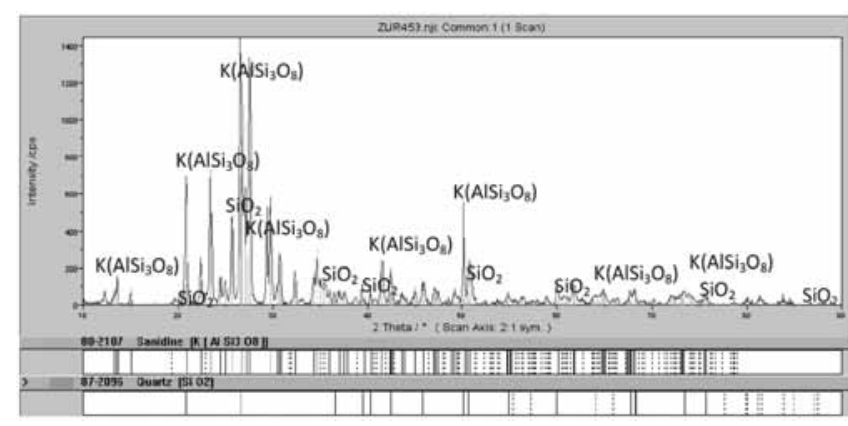

Rys. 4. Morfologia ziaren proszku miedzi użytego do badań Fig. 4. Morphology of electrolitic copper powder
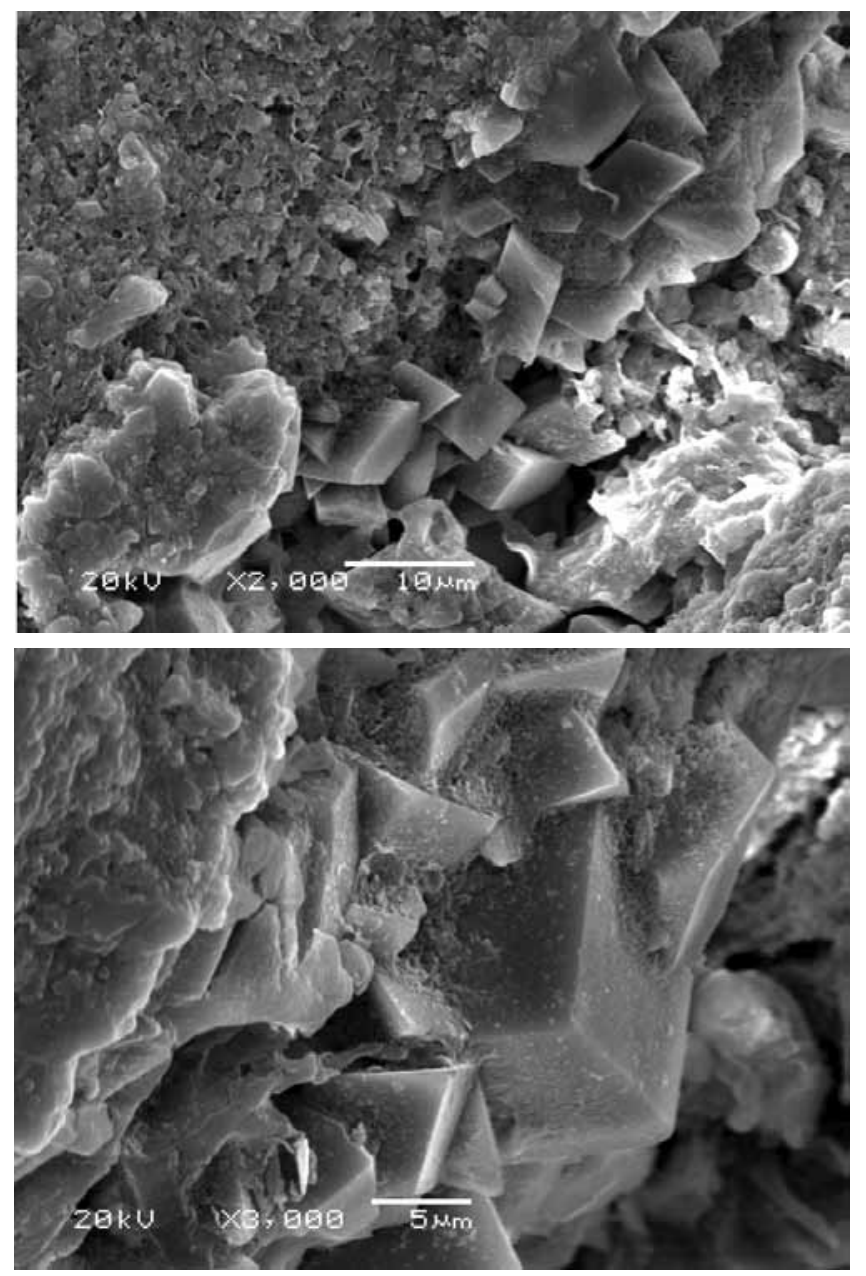

Rys. 5. Tuf wulkaniczny w postaci skały - widoczne frakcje występujące w tufie: kryształy sanidynu w osnowie mikrokrystalicznej Fig. 5. Microstructure of Filipowice tuff

prasowania $200 \mathrm{MPa}$. Aby obniżyć współczynnik tarcia pomiędzy proszkiem a ściankami matrycy zastosowano smarowanie ścianek matrycy stearynianem cynku. Próbki wykonano w kształcie walców o wymiarach $\emptyset$ 20x5 mm, przeznaczone do badania gęstości, badań struktury, temperatury mięknienia i przewodności elektrycznej. Do wytworzenia nasadkowych elektrod zgrzewalniczych wykonano próbki w kształcie walców o wymiarach Ø $30 \times 25 \mathrm{~mm}$. Proces spiekania przeprowadzono w laboratoryjnym piecu rurowym w temperaturze $900{ }^{\circ} \mathrm{C} \mathrm{w}$ atmosferze azotu. Czas spiekania izotermicznego próbek wynosił 60 minut. Po procesie
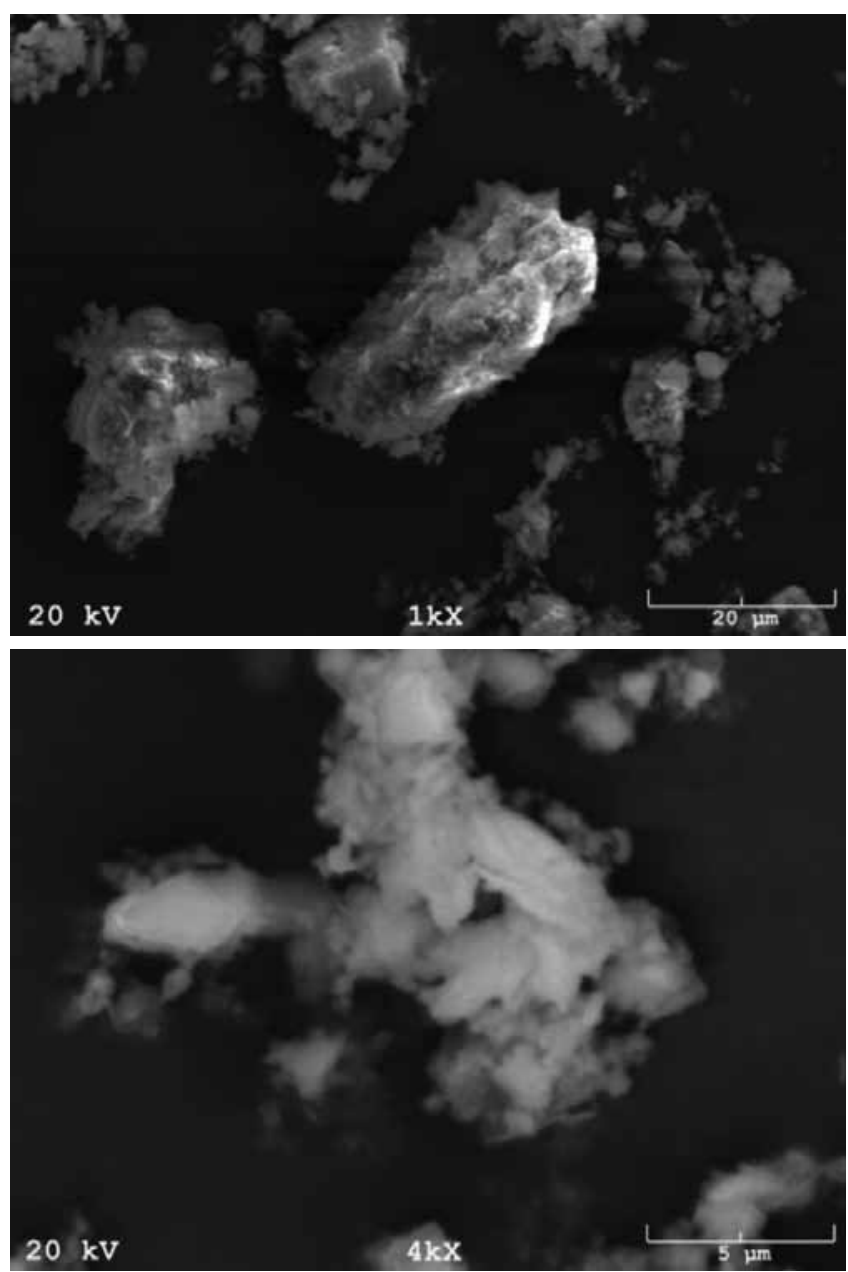

Rys. 6. Tuf wulkaniczny w postaci proszku wprowadzany do osnowy metalu

Fig. 6. Volcanic Tuf powder added to the metal matrix

spiekania próbki stygły razem z piecem. Zastosowano wolne nagrzewanie do temperatury izotermicznego spiekania z szybkością $10^{\circ} \mathrm{C} / \mathrm{min}$.

Gęstości teoretyczne tak przygotowanych kompozytów przedstawiono w tablicy 2.

Tablica II. Gęstości teoretyczne spieków

Table II. The theoretical density of composites

\begin{tabular}{|c|c|}
\hline Zawartość tufu & Gęstość teoretyczna DT g/cm3 \\
\hline $5 \%$ obj. tufu & 8,59 \\
\hline $15 \%$ obj. tufu & 7,95 \\
\hline $30 \%$ obj. tufu & 6,98 \\
\hline
\end{tabular}

Na rysunkach 7 i 8 przedstawiono fotografie przełomów kompozytów z 30\% i 15\% dodatkiem tufu wulkanicznego. Widoczny jest wyraźnie odmienny charakter przełomów niż w przypadku czystego metalu. $\mathrm{Na}$ rysunku 8 widoczne są cząstki tufu, które są pokryte bardzo małymi cząsteczkami. Mikroanaliza tych obszarów wykazała, iż jest to miedź.

Zjawisko to jest potwierdzeniem tego, iż uzyskano bardzo dobre połączenie cząstek tufu z osnową. 


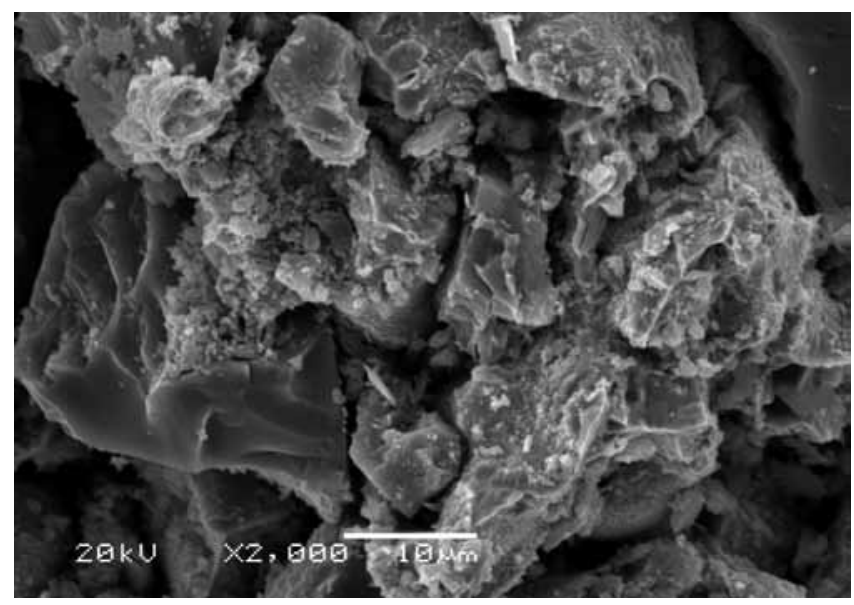

Rys. 7. Przełom kompozytu miedzi z $30 \%$ dodatkiem tufu Fig. 7. Fracture topography of copper composite with $30 \%$ of tuff

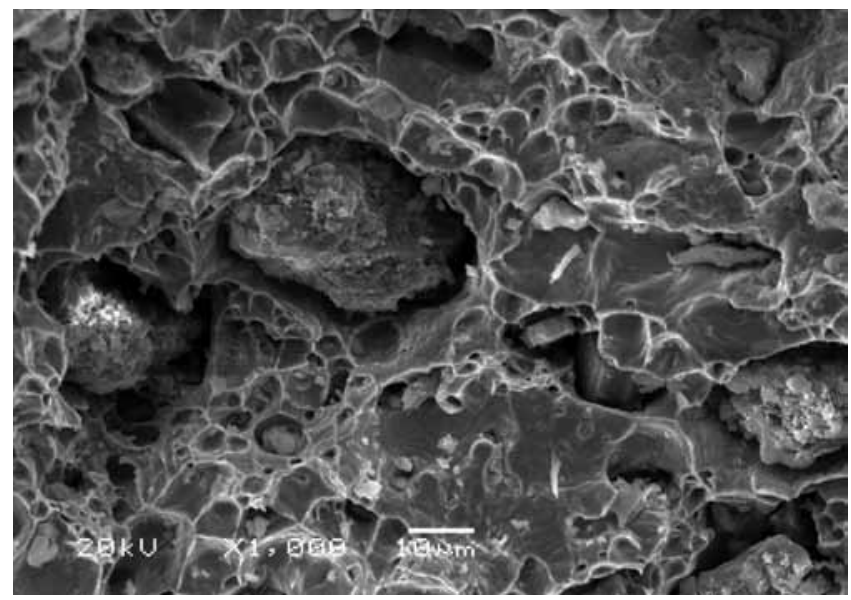

Rys. 8. Przełom kompozytu miedzi z $15 \%$ dodatkiem tufu

Fig. 8. Fracture topography of copper composite with $15 \%$ of tuff

Na rysunku 9 przedstawiono mikrostrukturę kompozytów z tufem wulkanicznym. Widoczne jest równomierne rozmieszczenie tufu w osnowie oraz ich dobre połączenie z miedzią. Nie stwierdzono nieciągłości na granicy tuf-osnowa. Analizy składu chemicznego nie stwierdziły rozpuszczania się składników tufu w osnowie. W tego typu kompozytach, biorąc pod uwagę ich możliwości aplikacyjne bardzo ważnym zagadnieniem jest czystość miedzi, która ma ogromny wpływ na jej przewodność elektryczną.

Na rysunku 10 przedstawiono zależność twardości kompozytów z tufem od temperatury ich wygrzewania (tzw. temperatura mięknienia). Dodatek tufu wpływa na twardość kompozytów w podwyższonej temperaturach. Dla spieku czystej miedzi zaobserwowano bardzo gwałtowny spadek twardości już w temperaturze około $200{ }^{\circ} \mathrm{C}$. Kompozyty z tufem wulkanicznym zachowują swoje właściwości do temperatury około $600^{\circ} \mathrm{C}$.

Badania przewodności elektrycznej kompozytów wykonano przy pomocy urządzenia SIGMATEST $w$ Instytucie Spawalnictwa w Gliwicach. Urządzenie to polega się na działaniu prądów wirowych, mierzy przewodność elektryczną metali nieżelaznych na podstawie impedancji zespolonej sondy pomiarowej.
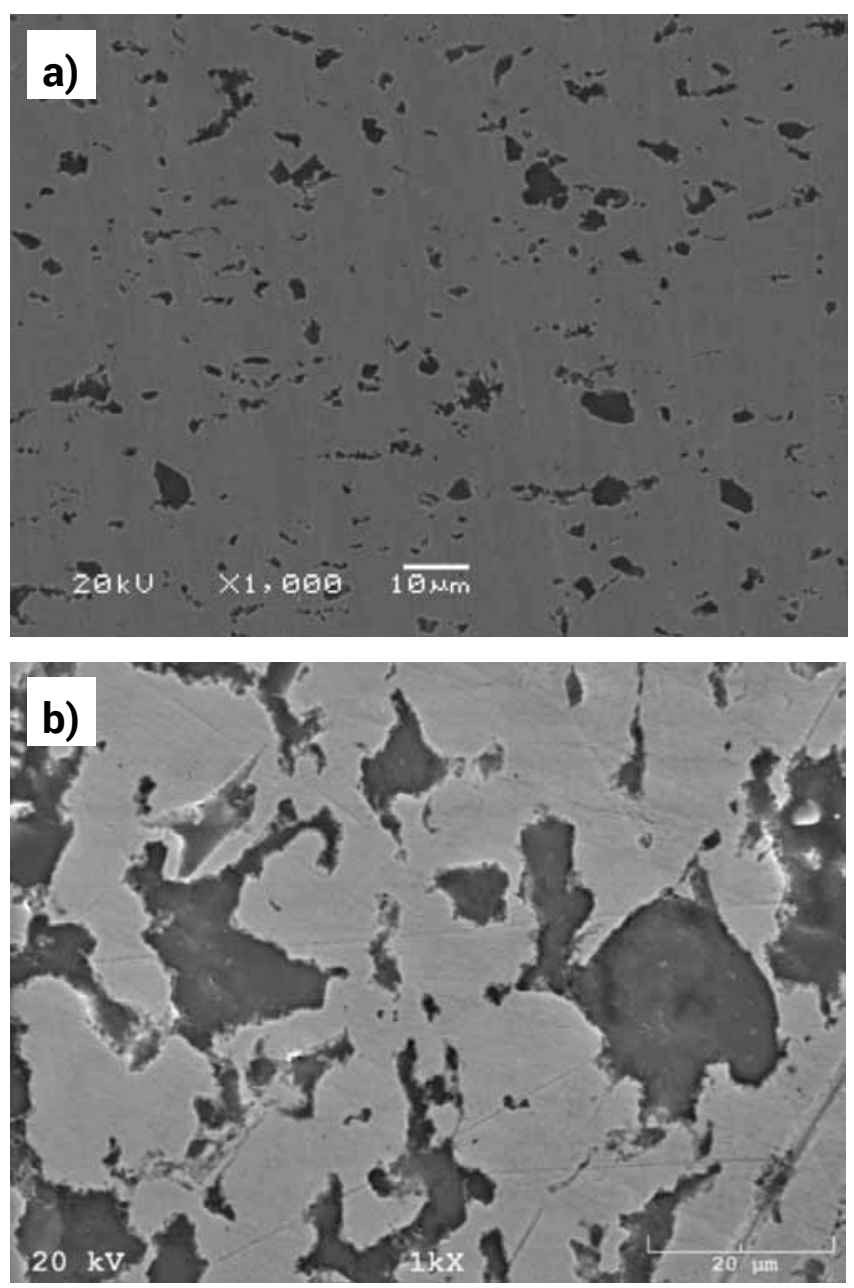

Rys. 9. Mikrostruktura kompozytów miedzi z dodatkiem tufu wulkanicznego $\mathrm{w}$ stanie nie trawionym: a) $\mathrm{Cu}+5 \%$ tufu $(<5 \mu \mathrm{m})$; b) $\mathrm{Cu}+30 \%$ tufu $(<40 \mu \mathrm{m})$

Fig. 9. Microstructure of copper composite with tuff: a) $\mathrm{Cu}+5 \%$ tuff $(<5 \mu \mathrm{m}) ;$ b) $\mathrm{Cu}+30 \%$ tuff $(<40 \mu \mathrm{m})$

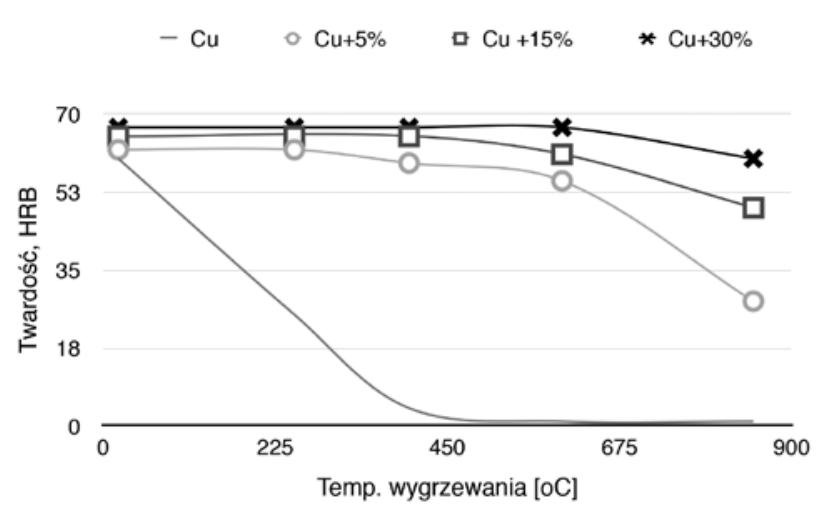

Rys. 10. Zależność twardości HRB od temperatury wygrzewania kompozytów z tufem [14]

Fig. 10. Influence of annealing temperature on the hardness (HRB) of composites with tuff [14]

Wyniki przeprowadzonych pomiarów przedstawiono na rysunku 11 . Pomiary przeprowadzono na próbkach nie dogęszczanych. Czysty spiek miedzi posiada przewodność elektryczną około $20 \%$ mniejszą niż miedź lita ze względu na występowanie porów. Dodatek $5 \%$ obj. tufu powoduje niewielkie zmniejszenie przewodności 
w porównaniu do spieku czystej miedzi i odpowiada wymaganiom normy ISO 5182 (materiały na elektrody do zgrzewania oporowego).

(IACS - International Annealed Copper Standard)

Zwiększenie ilości wprowadzonego tufu skutkuje stopniowym zmniejszaniem przewodności elektrycznej. Dla kompozytu zawierającego 15\% tufu wartość przewodności wynosi około 48\% IACS, natomiast dla $30 \%$ tufu wartość ta spada do około $28 \%$ IACS. Pomimo niskiej przewodności takich kompozytów ich wykorzystanie na elektrody do zgrzewania oporowego jest również możliwe. Norma ISO 5182 klasyfikuje na elektrody zgrzewalnicze również materiały o takich parametrach przewodności elektrycznej.

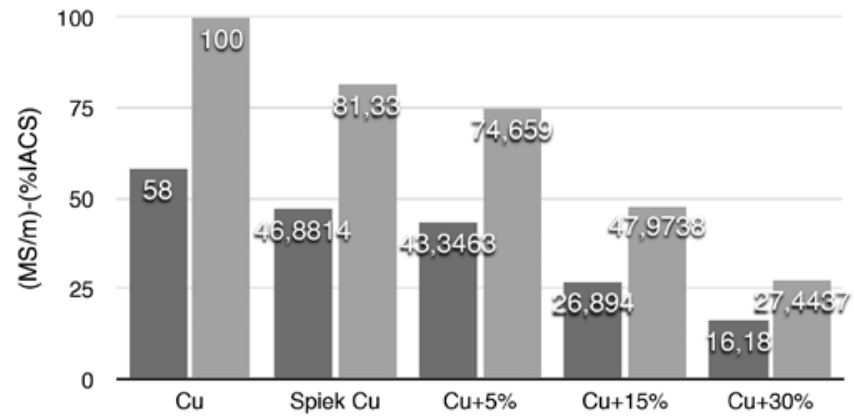

Rys. 11. Wartości przewodności elektrycznej dla wytworzonych kompozytów z tufem [13]

Fig. 11. The values of electrical conductivity for composites with tuff [13]

Na rysunku 12 przedstawiono zależność gęstości właściwej spiekanych kompozytów z tufem od ilości wprowadzonego tufu. Zauważalny jest wzrost gęstości właściwej kompozytów zawierających tuf, w porównaniu do spieku czystej miedzi.

$$
\text { - } \mathrm{MS} / \mathrm{m} \text { IACS }
$$

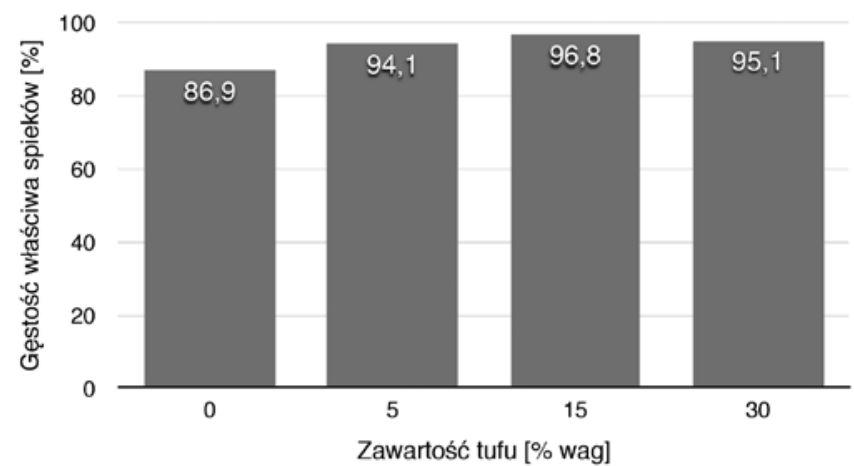

Rys. 12. Gęstość właściwa [w \%] spiekanych kompozytów w zależności od zawartości tufu

Fig. 12. Specific gravity of composites with tuff

Po badaniach właściwości kompozytów z tufem wykonano z nich nasadkowe końcówki elektrod do zgrzewania oporowego w celu przeprowadzenia wstępnego testu trwałości takich elektrod. Ze względu na dobrą przewodność elektryczną oraz inne właściwości, elementy takie wykonano z kompozytu zawierającego

$5 \%$ obj. tufu. W początkowym etapie wykonano jedynie płaskie powierzchnie robocze elektrod o średnicy wierzchołka $5 \mathrm{~mm}$ i przymocowano do elektrod w procesie lutowania. Rozwiązanie to przedstawiono na rysunku 13. Wykonano w ten sposób kilkaset zgrzein punktowych, blach stalowych o grubości $1 \mathrm{~mm}$. Nie stwierdzono żadnych oznak deformacji materiału. Kolejnym etapem było wytworzenie nasadkowych końcówek elektrod do zgrzewania punktowego. Wykonano je poprzez obróbkę skrawaniem. Końcówki te przedstawione zostały na rysunku 14. W tym przypadku wykonano około 1000 zgrzein punktowych i również nie stwierdzono deformacji części roboczych elektrod. Każdorazowo po wykonaniu kilkudziesięciu zgrzein, mierzono średnice elektrod. W tym celu wykonywano odwzorowania powierzchni elektrod poprzez wykorzystanie kalki dentystycznej. Nie zauważono zwiększania się średnicy elektrod. Ze względu na to, iż były to wstępne badania, ich wyniki nie są prezentowane w niniejszej pracy. Należałoby przeprowadzić testy na zautomatyzowanych zgrzewarkach przy wykonaniu kilku tysięcy zgrzein punktowych.

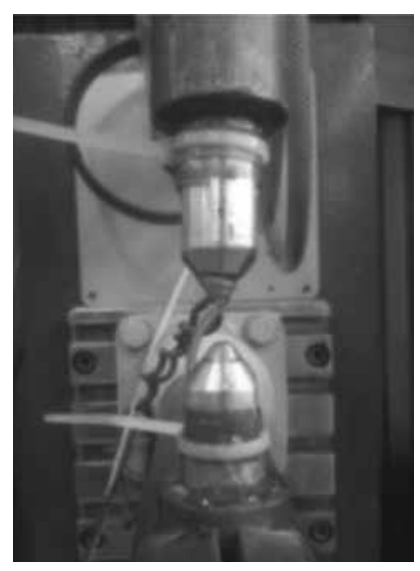

Rys. 13. Końcówki elektrod wykonane $z$ kompozytu z tufem i przylutowane do elektrod Fig. 13. The tips are made of a composite with tuff and soldered to electrodes
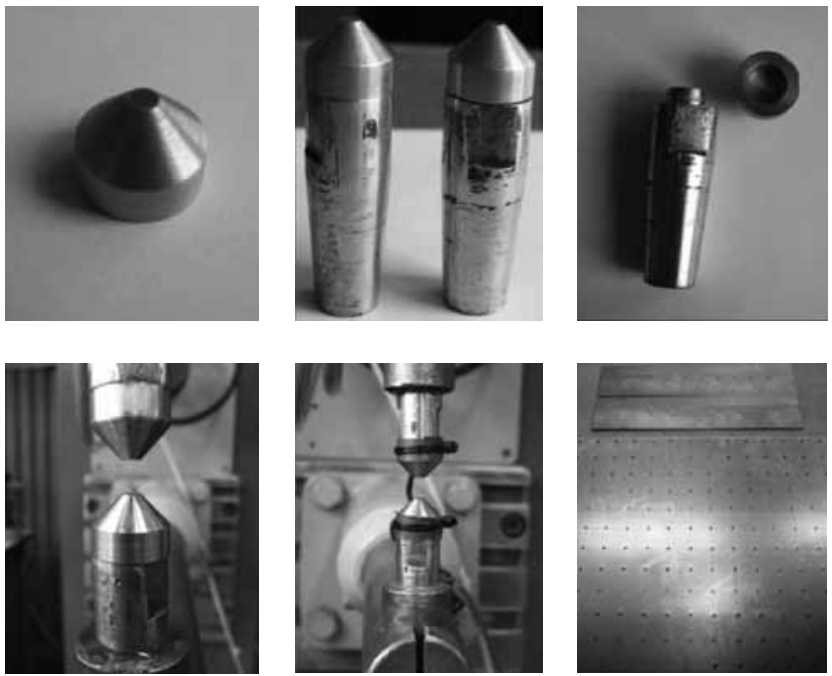

Rys. 14. Nasadkowe końcówki elektrod do zgrzewania oporowego wykonane z kompozytu z tufem oraz płyty na których przeprowadzano testy trwałości elektrod

Fig. 14. The nozzle tips of resistance welding electrodes and test series of spot welds 


\section{Podsumowanie i wnioski}

Wyniki przedstawionych badań pozwalają stwierdzić, że ceramika pochodzenia wulkanicznego jak np. tuf wulkaniczny jest materiałem mogącym znaleźć zastosowanie w produkcji kompozytów na osnowie metali. Dodatek rozdrobnionego tufu wulkanicznego w spiekanych kompozytach na osnowie miedzi, powoduje zmniejszenie ich porowatości a także zwiększenie temperatury mięknienia. Kompozyty takie mogą z powodzeniem być stosowane jako materiał na elektrody do zgrzewania oporowego. W wyniku wstępnych badań stwierdzono, że elektrody takie mogą charakteryzować się podwyższoną trwałością. Dodatek tufu obniża przewodność elektryczną kompozytów, jednak wartości tej przewodności są dopuszczalne według norm dotyczących materiałów na elektrody. Wytwarzając kompozyty z tufem poprzez technologię metalurgii proszków, uzyskuje się dobrą jakość połączenia ceramiki z metalową osnową.

Przedstawione rozwiązanie polegające na wykorzystaniu tufu wulkanicznego w kompozytach o osnowie metali zostało objęte ochroną patentową przez Urząd Patentowy Rzeczypospolitej Polskiej, numer PL 217818 - „Zastosowanie tufu wulkanicznego do umacniania spiekanych kompozytów na osnowie miedzi, spiekany kompozyt na osnowie miedzi umacniany cząstkami tufu wulkanicznego oraz sposób wytwarzania spiekanego kompozytu na osnowie miedzi umacnianego cząstkami tufu wulkanicznego".

\section{Literatura}

[1] Papkala H., "Zgrzewanie oporowe metali”, KaBe Krosno 2003

[2] Klimpel A., Spawanie, zgrzewanie i cięcie metali; WNT, Warszawa 1999.

[3] Gniewowski J.: „Wirbalit - materiał miedziowy różnorodnego zastosowania", Spajanie Metali i Tworzyw w Praktyce, 3/10/2005, 38-41.

[4] Bartnik Z., Derlukiewicz W., "Czynniki wpływające na trwałość elektrod do zgrzewania oporowego", Przegląd Spawalnictwa, 7/2006, 36-38.

[5] Mikno Z.; Bartnik Z.; Nagrzewanie elektrod w procesie zgrzewania rezystancyjnego punktowego (w obliczeniach MES); Seminarium: Spawalnictwo i procesy pokrewne w obliczeniach MES; Instytut Spawalnictwa w Gliwicach Maj 2012.

[6] Zhang H.; Senkara J.; Resistance Welding. Fundamentals and Applications; CRC Taylor and Francis, 2006.

[7] Paruzel S.; Cieliński M.; O miedziach stopowych stosowanych w zgrzewalnictwie: Porady praktyczne; Zgrzewanie metali I tworzyw w praktyce (1/1) 2002.

[8] ASM HANDBOOK, vol. 7, Powder Metallurgy.
[9] Głogowska M.; Walory edukacyjne odsłonięć geologicznych i obiektów górniczych w okolicy Trzebini,; Rozprawa doktorska AGH, Kraków 2007.

[10] Smolak W., Michalik M.; The lower permian filipowice tuff are there primary components in it?, Mineralogical society of poland - special papers, vol 20, 2002.

[11] Łach M., Structure of metal matrix composites with an addition of tuff, Archives of Foundry Engineering, Vol 10, Special Issue 3/2010, 135-140.

[12] Łach M., Struktura materiałów kompozytowych o osnowie metalowej z dodatkiem tufu, Materiały Konferencyjne, Jubileuszowa Międzynarodowa Konferencja Naukowa: Jakość i Innowacyjność w Inżynierii Materiałowej, Technologii i Budowie Maszyn, 23-25 Września 2010, Zakopane.

[13] Mikuła J., Łach M., Kompozyt miedź-tuf wulkaniczny. Wytwarzanie, własności i zastosowania; Czasopismo Techniczne 3-M/2011, zeszyt 5/108.

[14] Mikuła J., Łach M.; Potencjalne zastosowania glinokrzemianów pochodzenia wulkanicznego; Czasopismo Techniczne 8-M/2012, str. 111-124. 